\title{
Resource-and-Factor Approach to Clusters Competitiveness Development in Russia's Regions
}

\author{
Viktor Moseiko \\ Volgograd State University, \\ Institute of management and regional economy \\ Chair of Management \\ Volgograd, Russia \\ econmanag@volsu.ru
}

\author{
Sergey Korobov \\ Volgograd State University, \\ Institute of management and regional economy \\ Chair of Management \\ Volgograd, Russia \\ econmanag@ volsu.ru
}

\author{
Ekaterina Novoselceva \\ Volgograd State University, \\ Institute of management and regional economy \\ Chair of Management \\ Volgograd, Russia \\ econmanag@volsu.ru
}

\begin{abstract}
The authors of this article provide the main directions of the theory of clusters competitiveness development from the perspective of resource-and-factor analysis methodology. Special attention is paid to the processes of interaction of cluster members both with each other and with the external environment. The analysis of interaction types between economic entities within the cluster is conducted: direct and indirect, characterized by the presence or absence of direct contacts between cluster members. The processes of competition and cooperation within the cluster in terms of production, exchange and redistribution of available resources and factors are studied. The mechanisms necessary to ensure clusters successful functioning as territorial systems are highlighted. It is proved that any cluster shows its highest efficiency in cases when the participants interacting with each other in the processes of exchange and distribution of resources and conditions demonstrate cooperation, while in the process of production of cluster gross product they demonstrate competition. The main backbone feature of cluster organization management is detected, and it is self-production of business activities within the cluster. Some key integrating resources of cluster formations are defined and examined through the example of Russia's various regions.
\end{abstract}

Keywords - region, cluster, competition, cooperation, resources, factors, territorial systems, self-production

\section{INTRODUCTION}

Clusters as an effective form of territorial organization of economic entities' economic cooperation began to show themselves at the end of the XX century. The major scientific papers studying cluster phenomenon in territorial economy appeared in that period. In Russia, such studies on territorial economy cluster organization appeared in the early 2000s during the period of national economy development characterized by a fairly intensive formation of market relations and market institutions due to some favorable for our country macroeconomic conditions of that time.

\section{MATERIALS AND MethodS (MODEL)}

The resource-and-factor approach is most suitable for theoretical and empirical studies of various forms and models of spatial integration of regional production and, most importantly, of the conditions for clusters formation and functioning.

The influence of the resource-and-factor approach and of everything connected with it theoretically and methodically, is first of all conditioned by its noticeable effectiveness in identifying and justifying internal sources of economic systems competitive advantages at different levels.

The authors of this paper use the interpretation of resourceand-factor approach proposed in O.V. Inshakov's studies according to which resources exist in the state of natural objects, processes and conditions before getting into the 
process of appropriation,. Following that, the resources are transformed into production factors in the product manufacturing process. "First, natural objects and processes as external conditions should become resources and factors of production later on, but for this purpose their initial appropriation in labour process, regardless of its types, is necessary" [1]. In other words, natural objects, processes and conditions in form of resources-conditions appropriated by man, are involved as production factors in the production process. Then a finished product participates as a resource and factor in a new production process.

\section{RESULTS AND DISCUSSION}

A cooperative form of economic entities interaction, which is one of the main forms of regional production integration, is not something new for Russia's economic environment. Thus, management practice in different periods of Russia's economy development showed extremely high efficiency of cooperation as a tool of spatial production integration in terms of the development of management cooperative forms. Cooperative relations are also characteristic of cluster production organization in terms of integration relations between cluster members. In the modern period of market development, cooperative forms of spatial production integration get the imperatives for further development with regard to the market relations requirements [2].

The efficiency and effectiveness of economic entities functioning in various spheres of economic activity can significantly depend on their interaction. This is especially true for all forms of spatial agglomerations, since agglomeration already implies the coexistence of economic entities in a limited area, which is not possible without any relationships between these entities. Moreover, the form and content of such relationships (and of interactions caused by these relationships) fully determine these relationships nature within spatial agglomerations. In other words, mutual relations of economic entities determine the content nature of a corresponding model of spatial production integration: network organization, cluster, territorial production complex, industrial area, innovation system, etc.

Creation, production and marketing of specific goods, products or services are carried out through using and developing necessary production conditions, resources and factors by an economic entity. At the same time, mutual relations of economic entities within a spatial agglomeration are formed by them primarily on the assumption that the development or use of appropriate conditions, resources and factors in the production process should be mostly beneficial for economic entities.

In the interaction of cluster members, the transactional factors interact (connect) intensely (cost reduction takes place), and transformational factors interact extensively (cost reduction should not be expected) [3].

If the competitiveness of a cluster product produced by a particular cluster member is ensured by the resourcesconditions exchange/distribution processes, and later on by the processes of their development as production factors in a production process, the competitiveness of the cluster as a whole is formed in the result of all these processes.

We will reveal the competitiveness development process of territorial systems in the form of clusters in the following sequence of methodological grounds and generalizing conclusions:

1. First, the production process of the product in general can be represented as a sequence of three stages: purchase of necessary resources-conditions on the market; development of resources-conditions as production factors in the production process; sale of the finished product on the market. In the process of reproduction, the product sold on the market is a resource-condition for the production of a new product. Therefore, the stage of necessary resources-conditions market acquisition and the stage of finished product sale can be identified as the processes of resources-conditions exchange/distribution Thus, production of the product is based on two types of processes: the processes of resourcesconditions exchange/distribution and the processes of their development as appropriate production factors.

2. There are two types of interaction between business entities within a cluster: direct and indirect, characterized by the presence or absence of direct contacts between cluster members. We propose to consider the case when there is a direct interaction of cluster members without joint efforts as a process of their cooperation. In cooperation, there is no joint use of certain resources-conditions, and hence their joint development. Joint efforts in the case of cluster members' direct cooperation imply such interaction in which entities are engaged in joint use of certain resources and conditions. It means that they jointly develop relevant production factors in the production process. This process is proposed to be identified as cooperation between cluster members who can combine their efforts both in goods and services production, and in the sphere of their purchase and sale [4].

Competition is caused by the relations developing between cluster participants concerning superiority achievement in mutual rivalry (competition, contest). It is obvious that such interactions between cluster members occur mainly beyond direct contacts, i.e. indirectly.

3. Cooperation in a cluster means joint development of production factors by several economic entities - cluster members, each of which may have individual production advantages, the combination of which in the production process provides these participants with competitive advantages either over other cluster members (outside this cooperation), or over economic entities outside this cluster. As the development of transformation production factors dominates in the production process of the cluster product, combining efforts on their development occurs extensively, that is, cost reduction should not be expected. Cooperation in the process of resources-conditions exchange and distribution in a cluster means either their purchase or their sale as finished goods and services on the basis of joint efforts. The process of resources-conditions exchange/distribution is mainly dominated by transactional production factors, and this allows to expect cost reduction of their development given their intensive combination [5]. 
4. The competitiveness of the economic system product as a whole is formed in two phases. When analyzing the competition process features within the cluster, we should pay special attention to the necessity of highlighting its two phases: first, the process of direct production, where the transformation of resources as production factors directly into a product or service takes place, and, second, the processes prior and subsequent to the production process, that is the process or processes of natural conditions and objects, as well as of finished products transformation through stocks into resources. During the last phase (before and after the process of direct production), the cluster members make market choices, ensure availability and purchase of the necessary natural conditions and objects, which thus become reserves, and then become resources for further production. In other words, product competitiveness can be ensured by efficient and effective acquisition of production resources, quality resources at their minimum purchase price, and then efficient and effective use of these resources in the production process of a quality product with minimal production costs. But in the cluster, the acquisition of production resources by its participants a priori ("by definition") is carried out with minimal costs, which encourages organizations to become (produce themselves) members of the cluster. It is the presence of the key condition-resource and cluster members' cooperation that ensures minimum costs [6]. The main competitive battle between cluster members, therefore, unfolds not "on the field" of resources purchase (and sale), but rather "on the field" of their further development in the production process. Relatively low costs of resources access and acquisition for all cluster members and manifestation (transfer) of competitive battle (presence of competition) in the process of direct production of goods/services, all this in general provide cluster members with a relatively high level of competitiveness of these goods/services on the market outside the cluster.

At the stage of natural conditions and objects transformation through stocks into resources, cluster members "cooperate" in various organizational forms in order to reduce any costs and expenses at this stage. This can be shaped in the following procedures: common interests joint lobbying, joint efforts in market regulation, market promotion, information support, etc.

At the stage of resources transformation into product/service during the production process when resources become production factors, competition manifests itself in the form of "intercompany" conference where cluster participants - companies compete for the qualitative resources development in the production process.

With regard to the identification of interactions between cluster members proposed in this paper, competition in the cluster production process corresponds to the transformation phase of the competitiveness formation process, and competition in the cluster process of resources-conditions exchange and distribution corresponds to the transactional phase.

5. Cluster competition during the cluster production process occurs due to the manifestation of advantages and leadership in production factors development by each cluster member. Cluster competitiveness of the production process and, in many ways, competitiveness of the relevant cluster product, are determined by how effectively and efficiently the development of relevant factors in the production process is conducted.

The efficiency of a cluster product should be considered as the ability of a cumulative product produced by all cluster members to meet the needs of the market, users, customers, etc. At the same time, the efficiency of a cluster product is determined by unit costs, expenditures, expenses, etc., jointly spent per unit of a cluster product. It is obvious that both the consumer qualities of a cluster product, which determine consumer satisfaction, and the performance indicators of its production - all of them, are formed in the production process and depend on how the production factors development is carried out in this process. Thus, the competitiveness of the cluster product is formed during its production process and is determined by the relevant production factors development. Competitiveness of a cluster product in the production process is defined as its competitiveness in the first (transformational) phase of its formation [7].

6. Cluster competition in the resources-conditions exchange and distribution process occurs due to the fact that each participant provides advantages and leadership in the acquisition of the resources-conditions necessary for the production of a cluster product, as well as in the market sale of finished cluster product.

At the stage of acquiring resources-conditions, competition consists in the advantages and leadership that cluster members seek to provide for themselves as buyers. The appropriate resources-conditions such as previously produced goods and services at this stage demonstrate corresponding competitiveness of the second (transactional) phase of its formation.

At the stage of selling the finished cluster product, competition consists in the advantages and leadership that cluster members seek to provide for themselves as sellers. The corresponding cluster product as resources-conditions necessary for new production shows corresponding competitiveness of the second (transactional) phase at this stage.

It should be noted that in general, cluster members who are producers of a cluster product may not be the subject (or subjects) of competitiveness formation in the second (transactional) phase. In other words, selling resourcesconditions for the cluster production process and selling the finished cluster product as a resource for new production can be carried out by another member of the cluster. That is, cluster members who are not producers of the cluster product can become subjects of the cluster product competitiveness formation process at the stages of its sale. If business entities that are initially outside the cluster become such subjects, they turn to be members of the cluster automatically as they are involved in the cluster functioning processes. 
The main system-forming feature of the cluster management organization is the condition of self-production of entrepreneurial activity within the cluster. As a result of this condition, interaction of each business entity with other subjects of a territorial cluster depends only on itself, and on its decision concerning economic expedience of such interaction. In each case, such integrating condition becomes the most important key factor in clusters development and self-production of entrepreneurial activity in them. It is necessary to detect resources the development of which is a key to the formation of self-production conditions. To understand this, let's consider the following hypothetical example. In Primorye (in the Far East of the Russian Federation) fishing and fish processing industry is developing in the format of regional industry clusters. Can such a cluster function in the territory of Kalmykia? Obviously, it can't. Neither it is possible in this Republic to organize, for example, a cluster for timber extraction and processing. It should be noted that even with the sufficient development of other necessary resources-conditions such as material (financial), human (trained workers and specialists), organizational (decision-making), the organization and operation of fish processing and forest processing clusters is an economically inappropriate idea for such a region as Kalmykia. That is why, such resources as fish stocks in Primorye and forest reserves in Karelia and Siberia represent exceptional resource conditions for the relevant clusters operating in these regions, and entrepreneurial activity in the relevant territorial clusters is self-generated due to the availability of the key resource conditions first of all [8].

The key or integrating resource as a production factor plays the role of a cluster economic "locomotive" in the development of other resources necessary for the formation of self-production conditions (funds, trained workers and specialists, production and technological base, policy decisions), but not vice versa (see Table 1).
TABLE 1. THE KEY CONDITION/RESOURCE FOR CLUSTER MEMBERS INTEGRATION

\begin{tabular}{|c|c|}
\hline Management systems & Key integration resource-condition \\
\hline $\begin{array}{l}\text { "Autograds" in the cities of } \\
\text { Togliatti, Naberezhnye } \\
\text { Chelny, N-Novgorod, } \\
\text { Kaliningrad, Vsevolozhsk. }\end{array}$ & $\begin{array}{l}\text { Car production by large enterprises. } \\
\text { Produced resource-condition is of } \\
\text { artificial nature. }\end{array}$ \\
\hline $\begin{array}{l}\text { Forestry enterprises, } \\
\text { complexes of Vologda } \\
\text { Oblast, Karelia, Siberia, etc. }\end{array}$ & $\begin{array}{l}\text { Presence of forest reserves. Resource- } \\
\text { condition is natural. }\end{array}$ \\
\hline $\begin{array}{l}\text { Agricultural enterprises of } \mathrm{f} \\
\text { Krasnodar Krai. }\end{array}$ & $\begin{array}{l}\text { Natural landscape and climatic } \\
\text { conditions. Resource is a condition of } \\
\text { natural character. }\end{array}$ \\
\hline $\begin{array}{l}\text { Sanatorium-resort } \\
\text { tourist companies of } \\
\text { Krasnodar and Stavropol } \\
\text { Krais (resorts on the Black } \\
\text { Sea coast and in the North } \\
\text { Caucasus of the Russian } \\
\text { Federation). }\end{array}$ & $\begin{array}{l}\text { Natural-landscape and climatic } \\
\text { conditions. Resource-condition is } \\
\text { natural. }\end{array}$ \\
\hline $\begin{array}{l}\text { Fisheries and processing } \\
\text { enterprises of the Caspian } \\
\text { Sea, Primorye, the Baltic } \\
\text { region, etc. }\end{array}$ & $\begin{array}{l}\text { Availability of seafood stocks and } \\
\text { marine bioresources. Resource-condition } \\
\text { is natural. }\end{array}$ \\
\hline $\begin{array}{l}\text { Modern regional business } \\
\text { incubators. }\end{array}$ & $\begin{array}{l}\text { Presence of specific scientific } \\
\text { knowledge. Scientific, production and } \\
\text { research infrastructure. } \\
\text { Produced resources-conditions are of } \\
\text { artificial nature. }\end{array}$ \\
\hline $\begin{array}{l}\text { Metallurgical and } \\
\text { metalworking enterprises of } \\
\text { the South Urals. }\end{array}$ & $\begin{array}{l}\text { Production of metallurgical products by } \\
\text { large enterprises. Produced resource- } \\
\text { condition is of artificial nature. }\end{array}$ \\
\hline $\begin{array}{l}\text { Modern trade, trade and } \\
\text { exhibition, shopping and } \\
\text { entertainment centers. }\end{array}$ & $\begin{array}{l}\text { Trade and logistics infrastructure and } \\
\text { information resource. Produced } \\
\text { resources-conditions are of artificial } \\
\text { nature. }\end{array}$ \\
\hline $\begin{array}{l}\text { Enterprises for vegetables } \\
\text { production and processing } \\
\text { in the Volgo-Akhtuba } \\
\text { floodplain of Volgograd } \\
\text { Oblast in the USSR period. }\end{array}$ & $\begin{array}{l}\text { Natural-landscape and climatic } \\
\text { conditions. Resource-condition is } \\
\text { natural. Presence of flood irrigation } \\
\text { system. Produced resource-condition is } \\
\text { of artificial nature. }\end{array}$ \\
\hline $\begin{array}{l}\text { Enterprises for jewelry and } \\
\text { souvenirs production } \\
\text { located on the territory of } \\
\text { one municipal entity: Red- } \\
\text { on-Volga in Kostroma } \\
\text { Oblast, Kubachi in } \\
\text { Dakhaevsky Raion, } \\
\text { Republic of Dagestan. }\end{array}$ & $\begin{array}{l}\text { Presence of special production } \\
\text { knowledge. Produced resource-condition } \\
\text { is of artificial nature. }\end{array}$ \\
\hline $\begin{array}{l}\text { Artel extraction of furs in } \\
\text { different regions of Siberia. }\end{array}$ & $\begin{array}{l}\text { Presence of fur-bearing animals. } \\
\text { Resource is a condition of natural } \\
\text { character. }\end{array}$ \\
\hline
\end{tabular}

The key resource presence is a very important condition for ensuring self-production conditions for entrepreneurial activity.

\section{CONCLUSION}

The analysis of all the methodological grounds and generalized findings allows us to draw the following conclusions:

- cluster members provide themselves and the cluster as a whole with the best competitive advantages in the case when interacting with each other they cooperate in resourcesconditions exchange/distribution processes (including cluster 
products) and compete in the production of gross cluster product;

- if competition in the production process of industrial agglomeration total product is completely "replaced" by cooperation of this agglomeration participants, the corresponding spatial set of enterprises can represent a simple network structure - enterprises network. Such agglomeration cannot be considered a cluster, because, firstly, the production of the final product is not based on the competitive development of production factors, and, secondly, the cooperative interaction of system entities within the network increases its closeness and reduces free access to the key integrating resource, and this fact generally becomes an essential barrier to self-production of entrepreneurial activity in this agglomeration. In addition, we should say that given the reduction of competition through cooperation, a decrease in competitive pressure and, consequently, cluster members aspirations to innovative development may take place, and individual companies are likely to be more competitive than those joined into a cluster;

- if cooperation is completely "replaced" by competition both in the resources and conditions exchange/distribution processes, and in the process of total product production, then the corresponding spatial set of enterprises can represent a simple agglomeration of industrial enterprises. Such agglomeration cannot be considered a cluster, since a high level of competition both at the stage of resource provision and at the stage of production may be a barrier for selfproduction of entrepreneurial activity in this agglomeration;
- self-production of entrepreneurial activity, in general, without reference to cluster management organization, is stimulated by the access to production resources acquisition. In the case of cluster production organization, self-production of entrepreneurial activity is conditioned, first of all, by the availability of the key resources-conditions.

\section{References}

[1] Inshakov OV, (2004) The level-sensitive analysis of the object, subject and method of economic theory. Izv St Petersburg Univ Econ Financ 4:5-18.

[2] Moseiko VO, Korobov SA, Tarasov AV (2015a) Cognitive modelling in decision-making: resource-factor analysis potential. Creat Econ 9(5):629-644. doi:10.18334/ce.9.5.267.

[3] Potter, J., \& Miranda, G. (2009). Clusters, Innovation and Entrepreneurship (p. 233). OECD.

[4] Porter, M. E. (1990). The Competitive Advantage of Nations (p. 896). London, Macmillan.

[5] Andersson, T., Schwaag-Serger, S., Sorvik, J., \& Wise Hansson, E. (2004). The Cluster Policies Whitebook,IKED (p. 250)..

[6] Visser, E.-J., \& Boschma, R. (2002). Clusters and networks as learning devices for individual firms. Retrieved February 15, 2015, from http://ecsocman.hse.ru/data/463/656/1219/clust.pdf

[7] Wise, E., \& Johansson, C. (2012). Where the cluster winds are blowing in Europe. Better cluster policies and tools for implementation. Retrieved February 16, 2015, from http://www.vinnova.se/upload/EPiStorePDF/

Tactics_ClusterWinds.pdf.

[8] Moseiko, V.O., S.A. Korobov and D.P. Frolov, 2015. Socio-Economic Systems' Competitiveness Assessment Method. Asian Social Science, 11 (20):1-8. DOI:10.5539/ass.v11n20p1. 